\title{
Demodicose felina em Santa Catarina, Brasil ${ }^{*}$ Feline demodicosis in Santa Catarina state, Brazil
}

\author{
Mariana Almeida Oliveira, ${ }^{* *}$ Marcy Lancia Pereira, ${ }^{* * *}$ Alexandre de Oliveira Tavela***
}

\begin{abstract}
Resumo
A demodicose felina é considerada uma dermatopatia rara e pode ser causada pelos ácaros Demodex cati, Demodex gatoi e uma terceira espécie ainda não nomeada. Foi atendido um felino adulto apresentando prurido intenso há 9 meses e histórico de tratamento com cefalexina e prednisolona, com piora progressiva. Ao exame físico, havia alopecia, hiperqueratose, escoriações e eritema em cabeça, pescoço, região lombossacra, cauda e membros pélvicos, além da presença de pulgas. Para puliciose, foram prescritos selamectina spot on a cada 30 dias e uso de amitraz no ambiente a cada sete dias e, para controle da infecção secundária pelas escoriações, foram recomendados banhos semanais com clorexidine. Realizaram-se raspado de pele profundo e arrancamento de pelos para tricograma e exame parasitológico de pele, respectivamente, com diagnósticos de demodicose por Demodex cati, e dermatite micótica associada a infecção bacteriana secundária. $\mathrm{O}$ tratamento foi modificado para uso de selamectina a cada 2 semanas, mas tutor não retornou e informou, após vários meses, ter feito terapia com selamectina apenas a cada 30 dias e descontinuidade dos banhos. Não foi possível associar a demodicose, para este felino, a outras comorbidades e acredita-se que a apresentação generalizada da doença tenha se dado pelo prurido causado pela puliciose.
\end{abstract}

Palavras chaves: amitraz, corticoide, demodiciose, gato, selamectina.

\section{Abstract}

Feline demodicosis is considered a rare dermatopathy and can be caused by Demodex cati, Demodex gatoi and a third species not yet named. An adult male feline was attended with severe pruritus for 9 months and a history of treatment with cephalexin and prednisolone, with progressive worsening. On physical examination, there was alopecia, hyperkeratosis, abrasions and erythema on the head, neck, lumbosacral region, tail and pelvic limbs, in addition to the presence of fleas. For pulicosis, selamectin spot on was prescribed every 30 days and use of amitraz in the environment every seven days. In order to control secondary infection, weekly baths with chlorhexidine were recommended. Deep skin scraping and hair plucking were performed for trichogram and parasitological skin examination, respectively, with diagnoses of demodicosis by Demodex cati, and mycotic dermatitis associated with secondary bacterial infection. The treatment was modified to use selamectin every 2 weeks, but the tutor did not return and reported, after several months, that he had done therapy with selamectin only every 30 days and discontinued baths. For this feline, it was not possible to associate demodicosis with other comorbidities. It is believed that the generalized presentation of the disease occurred due to the pruritus caused by pulicosis.

Keywords: amitraz, corticoids, demodicosis, cat, selamectin.

\section{Introduction}

Demodicosis in an inflammatory disease associated with cutaneous overpopulation of Demodex spp.. Unlike the canine disease, feline demodicosis is considered a rare condition in small animal practice, with approximately four cases per 10,000 cats (Bizikova, 2014). Whereas, kittens are rarely affected, when present, mite infestations have been reported in cats with over one year of age (Matricoti and Maina, 2017). Feline demodicosis can be caused by three species of Demodex mites: $D$. gatoi, $D$. cati, and a yet unnamed species. $D$. cati presents a similar long and thin morphology as the $D$. canis. It resides in hair follicles, glands, and sebaceous ducts and can be found in healthy cats, as a part of the natural microfauna of the feline skin (Beale, 2012a).

Feline demodicosis, caused by $D$. cati, is believed to be associated with underlying immunosuppressive diseases (Beale, 2012a). Cats with demodicosis present erythema, hypotricosis/ alopecia, crusting, scaling, and various degrees of pruritus (Mueller et al., 2020). This skin condition can be either, localized or generalized. While in the localized form, the lesions are usually distributed over the head and neck, and affect mainly the ear, muzzle, and periocular region; in the generalized form, the lesions may also extend to the trunk and limbs (Horne, 2020).

Demodicosis diagnosis should be carried out by clinical signs, physical examination, and complementary tests (Mueller et al., 2020). In most cases, deep skin scraping is the diagnostic tool of choice, once it provides important information regarding the presence and the life stage of the $D$. cati. Trichogram, acetate tape technique, and skin biopsies can be used as alternatives. Also, therapeutic diagnosis can be performed by assessing the patient's response to miticidal treatment (Mueller et al., 2020).

\footnotetext{
*Recebido em 16 de julho de 2020 e aceito em 21 de setembro de 2020.

${ }^{* *}$ Graduanda de Medicina Veterinária da Universidade Federal de Santa Catarina (UFSC), Centro de Ciências Rurais, campus Curitibanos, Brasil.

***Docente, Centro de Ciências Rurais, Universidade Federal de Santa Catarina (UFSC), campus Curitibanos, Brasil.
} 
Generally, patients with localized disease have a spontaneous resolution (Matricoti and Maina, 2017). By contrast, patients with generalized demodicosis, should be investigated for underlying immunosuppressive or concurrent diseases, as well as treated with specific miticidal agents (Mueller et al., 2020).

Feline demodicosis caused by $D$. cati is a rare condition in feline clinical practice and only three cases were reported in Brazil (Lustoza and Silva, 2003, Pereira et al., 2005, Valandro et al., 2016). Thus, the present case report aimed to describe the first case of feline demodicosis caused by $D$. cati in Santa Catarina state, Brazil.

\section{Case report}

A three-year-old, $3.250 \mathrm{~kg}$, white coat, neutered male cat was referred to the Veterinary School of the Federal University of Santa Catarina (UFSC), Curitibanos campus, with a nine-month history of intense pruritus and with dermatological lesions extending from the neckline to other parts of the body. According to the tutor, the lesions began in the dorsal and ventral aspect of the cervical region. The cat was previously treated with cephalexin (30 mg/kg, PO), and prednisolone $(0.5 \mathrm{mg} / \mathrm{kg}, \mathrm{PO})$, twice daily for 30 days, however, no clinical improvement was noticed, and the lesions were increasing. Additionally, the patient lived with a healthy cat in the same household and presented an unknown vaccination and deworming history.

On physical examination, the cat presented body condition score 2/5 and hyperemic mucosa. Skin inspection revealed flea infestation, opaque hair and symmetrical areas of alopecia with erythema, papules, hyperkeratosis, erosions and crusts in the dorsal aspect of the head, neck, lumbosacral region, tail (Figure 1), and hind limbs. The patient presented unremarkable findings during the otoscopic evaluation and negative results for Woods lamp test. Trichogram and deep skin scraping of the affected areas were carried out for parasitological examination. Selamectin (Revolution $® 6 \%$, Zoetis, Brazil) spot on with 30 days interval and a weekly body bath with $2.5 \%$ chlorhexidine shampoo were initially prescribed for pulicosis. In addition, environmental treatment using a $12.5 \%$ amitraz solution was indicated for flea control in the target areas.
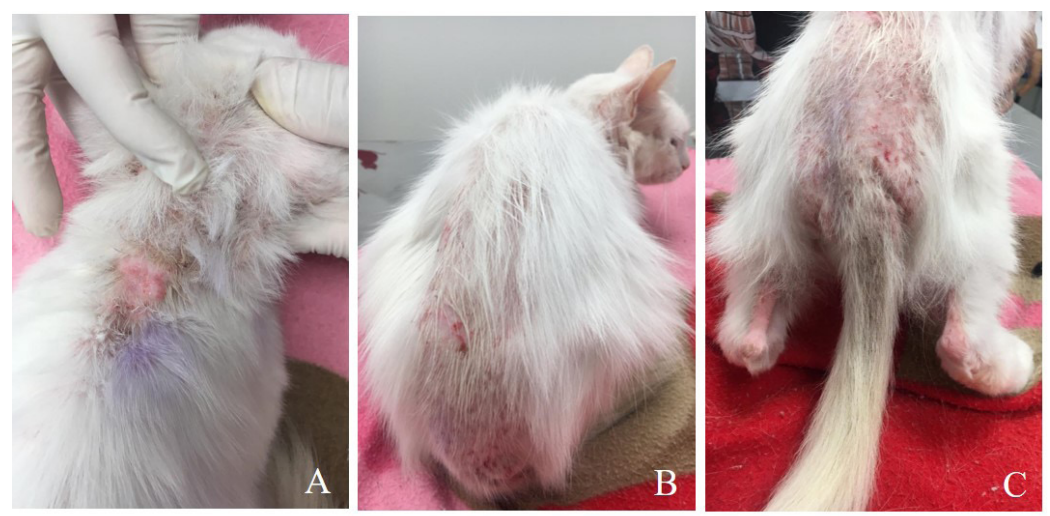

Figure 1: Alopecia, hyperkeratosis, abrasions and erythema on the dorsal aspect of the head and neck $(A)$, lumbosacral region $(B)$, tail and hind limbs $(C)$ of a feline patient with feline demodicosis caused by Demodex cati.
After one week, the patient was rechecked. The owner reported a slight skin improvement, despite no changes in the pruritus degree. Physical examination revealed a persistent flea infestation and a decrease of the skins' hyperkeratosis and hyperemia. Results of the microscopic evaluations of the plucked hair and multiple skin scrapings revealed the presence of Demodex cati mites. Trichogram showed bulging areas of the medulla with consequent rupture of this structure, innumerous filamentous structures along the other side of the hair shaft, moderate amount of amorphous material in the hair bulb, crusts along the hair shaft, fracture of the hair shaft with tapered edges, and telogenic deviation. Therefore, this exam suggested the diagnosis of mycotic dermatitis with a probable secondary bacterial infection.

Immunochromatography assays were performed to detect Feline Immunodeficiency Virus (FIV) and Feline Leukemia Virus (FeLV) (FIV Ac / FeLV Ag Test Kit, Alere Veterinary Diagnosis), however, both presented negative results. Thus, Selamectin prescription was readjusted for a fortnightly interval, and weekly body baths were maintained until further recommendations. The tutor did not attend to the 30 days follow-up as requested. Phone contact was made ten months later, and the tutor reported the maintenance of Selamectin treatment once a month and justified the discontinuation of the treatment due to its costs and personal issues. Nevertheless, the tutor reported an improvement in the patient's skin appearance, however, the cat still presented mild pruritus and the dermatological condition remained unresolved.

\section{Discussion}

Demodex cati mites can be found in healthy cats and is considered to be part of the natural microfauna of the feline skin. Similarly, to dogs, vertical infestation from mother to neonates is very likely to occur during lactation, however, there is a lack of studies describing demodicosis as a potentially transmittable disease (Mueller et al., 2020). Additionally, the vast majority of the affected cats are asymptomatics, and related cats may react differently to mite infestations on the dependence of their immune status (Matricoti and Maina, 2017). In the present report, a healthy cat was living in the same household as the affected cat and did not present clinical signs of demodicosis.

According to Beale (2012b), the disease caused by $D$. cati may be pruritic or not and, when in its localized form, it tends to involve the face. Once the patient presented concomitant pulicosis, it is difficult to point out if the pruritus was caused by flea infestation or demodicosis.

Despite being uncommon in an adult cat without systemic comorbidities, the patient was diagnosed with the generalized form of demodicosis due to the extensive body distribution of the skin lesions (Horne, 2020). Additionally, our findings suggest that the Demodex cati infestation started as the localized form, once primary lesions occurred in the dorsal and ventral aspect of the cervical region. Due to the presence of flea infestation, it is believed that the pruritus and excoriations led to the rupture of the skin barrier. Thus, this may have favored demodicosis dissemination. 
In the present report, the suspect of secondary bacterial infection is a common finding associated with demodicosis, and it may occur as a result of pruritus that leads to skin lesions and accumulation of secretions in the hair follicles. Crusts, alopecia, and erythema are frequent lesions in cats with pyoderma, of which is usually reported as a secondary infection in this specie (Yu and Vogelnest, 2012). According to Yu and Volgelnest (2012), the diseases that can cause secondary bacterial pyoderma includes allergic and inflammatory skin diseases, as well as parasitic diseases such as demodicosis and pulicosis. Bacteria from the genus Staphylococcus spp., in particular Staphylococcus pseudintermedius, are the most prevalent. Despite the absence of cytology and bacterial culture of the skin, in the present report, trichogram showed crusts along the hair shaft and a moderate amount of amorphous material in the hair bulb, suggesting a probable secondary bacterial infection that may have contributed to the worsening of the patient's clinical condition.

Based on the patient's clinical signs, differential diagnoses included dermatophytosis, pemphigus foliaceus, bacterial folliculitis, dermatitis / otitis caused by Otodectes cynotis, infestation by Notoedres cati, allergic dermatitis and cutaneous lymphoma (Beale, 2012a). Yu and Vogelnest (2012) described the use of antibiotics, such as cephalexin or amoxicillin clavulanate, as the treatment of choice for pyoderma. Therefore, previous treatment with cephalexin ruled out primary bacterial folliculitis due to the ineffectiveness of this specific therapy after 30 days. Allergic dermatitis was discarded, as there was no clinical response to the initial treatment with steroidal antiinflammatory drugs. Pemphigus foliaceus was also ruled out, due to incompatible clinical signs. Notwithstanding, cutaneous lymphoma was disregarded, as it usually affects geriatric patients and generalized pruritus is not a specific finding.

The absence of ear discharge, as well as auricular lesions during the otoscopic evaluation discarded otodectic otitis, once these findings are usually expected for this condition (Lustoza and Silva, 2003). Nevertheless, infestation by Notoedres cati was also excluded after parasitological screening. As for dermatophytosis, despite the negative result at the Wood's lamp test, the trichogram of the plucked hair suggested the diagnosis of mycotic dermatitis due to presence of filamentary structures along the outer side of the hair shaft, as well as fractures of the hair shaft with taper edges. Thus, if present, dermatophytosis would be considered a secondary disease, as well as pyoderma.

Feline demodicosis is frequently associated with positive testing for FIV/FeLV. However, Valandro et al. (2016) reported a negative FIV/FeLV feline patient with demodicosis, which presented as an associate cause, the presence of endoparasites in the digestive tract. In the present report, the cat presented negative results for FIV / FeLV and an outdated deworming protocol. Thus, despite the absence of fecal analysis to investigate the presence of helminths, internal parasitosis can't be ruled out as an associate cause.

\section{References}

BEALE, K. Feline demodicosis. Journal of Feline Medicine and Surgery, v. 14, n. 3, p. 209-213, 2012a.

BEALE, K. Feline Demodicosis - a consideration in the itchy or overgrooming cat. Journal of Feline Medicine and Surgery, v. 14, n. 3, p. 219-213, 2012b.
The use of selamectin spot on monthly and weekly use of amitraz in the environment was instituted at the first consultation, since flea control could play an important role in the pruritus. Additionally, selamectin is also effective as a miticidal agent and, despite contradictory results, when used weekly it is considered a viable option for feline demodicosis (Saari et al., 2009, Jánkzac et al., 2017). The use of amitraz solution in the environment doesn't apply for demodicosis treatment, however, if it had been used topically and in lower concentrations, it could be suitable for this purpose. In the latest consensus on canine and feline demodicosis (Mueller et al., 2020), amitraz, although potentially toxic, is a very effective and safe miticidal agent if used as body dips $(0.0125 \%$ for healthy, non-diabetic or with heart disease). Additionally, alternative treatments for demodicosis, with weekly dips of $2 \%$ sulfur solution or weekly administration of moxidectin associated with imidacloprid could be carried out. Single use of fluralaner was also reported as an effective therapy for feline demodicosis (Matricoti and Maina, 2017).

According to $\mathrm{Yu}$ and Vogelnest (2012), clorexidine $(2.5 \%)$ is an antiseptic agent that can be used alone or combined with systemic antibiotics such as cephalexin or amoxicillin clavulanate for superficial pyoderma. In the present report, a secondary superficial pyoderma was suspected; however, not proved. Thus, it is believed that, if the treatment was carried out as prescribed, better results could have been achieved.

At last, the authors emphasize that an efficient therapeutic protocol consists not only in defining the best clinical and drug management, the tutor's trust and cooperation are essential to perform the therapy correctly and maintain the veterinarian informed about any changes with the patient. The continuous monitoring of the feline patient is paramount to decide whether to maintain or change the medical prescription. However, due to the non-monitoring of the patient and the lack of collaboration from the tutor, it was not possible to assess the effectiveness of the prescribed therapy.

\section{Conclusions}

Feline demodicosis is considered to be a rare condition, however, it should be considered as a differential diagnose among other feline dermatopathies in Brazil. Therefore, it is essential to perform complementary exams for precise and definitive diagnosis. In the present report, clinical signs were in accordance with the findings described in literature. Thus, the authors presume that skin lesions started as a localized form of demodicosis, with lesions in the neckline that extended to other parts of the body and evolved to the generalized form due to pulicosis. In addition, selamectin spot on treatment can be considered as partially effective for feline demodicosis. However, due to the lack of the patient's monitoring, it was not possible to assess long-term therapeutic response.

BIZIKOVA, P. Localized demodicosis due to Demodex cati on the muzzle of two cats treated with inhalant glucocorticoids. Veterinary Dermatology, v. 25, p. 222-225, 2014.

HORNE, K. Demodicose Felina. In: HORNE, K. Dermatologia de pequenos animais para técnicos e enfermeiros: John Wiley \& Sons, Inc., p. 159-164. 2020. 
JAńCZAK, D; RUSZCZAK, A.; KASZAK, I.; GOLAB, E, BARSZCZ, K. Clinical aspects of demodecosis in veterinary and human medicine. Medycyna Weterynaryjna, v. 73, n. 5, p. 265271, 2017.

LUSTOZA, A.C.; SILVA, B.S. Otite externa associada a Demodex cati e Otodectys cynotis em felino. Brazilian Journal of Veterinary Research and Animal Science, v. 40, p. 172-172, 2003.

MATRICOTI, I.; MAINA, E. The use of oral fluralaner for the treatment of feline generalised demodicosis: a case report: a case report. Journal of Small Animal Practice, v. 58, n. 8, p. 476-479, 2017.

MUELLER, R.S.; ROSENKRANTZ, W.; BENSIGNOR, E.; KARAS-TECZA, J.; PATERSON, T.; SIHPSTONE, M.A. Diagnosis and treatment of demodicosis in dogs and cats. Veterinary Dermatology, v. 31, n. 1, p. 4-29, 2020.
PEREIRA, A.S.; SCHUBACH, T.M.P.; FIGUEIREDO, F.B.;

LEME, L.R.P.; SANTOS, I.B.; OKAMOTO, T.; CUZZI, T.; REIS, R.S.; SCHUBACK, A. Demodicose associada à Esporotricose e Pediculose em gato co-infectado por FIV/FeLV. Acta Scientiae Veterinariae, v. 1, n. 33, p. 75-78, 2005.

SAARI, A.S.; JUUTI, K.H.; PALOJARVI, J.H.; VÄISÄNEN, K. M.; RAJANIEMI, R. L.; SAIJONMAA-KOULUMIES, L. E. Demodex gatoi-associated contagious pruritic dermatosis in cats-a report from six households in Finland. Acta Vet Scandinavia, v. 51, n.1, p. 1-8, 2009.

VALANDRO, M.A.; PASCON, J.P.E.; MISTIERI, M.L.A.; GALLINA, T. Demodiciose felina por Demodex cati. Acta Scientiae Veterinariae, v. 44, n. 1, p. 172-176, 2016.

YU, H.W.; VOGELNEST, L.J. Feline superficial pyoderma: a retrospective study of 52 cases (2001-2011). Veterinary Dermatology, v. 23, n. 5, p. 448-86, 2012. 